\title{
ENVIRONMENTAL RESPONSIBILITY AND FIRM FINANCIAL PERFORMANCE: EVIDENCE FROM INTERNATIONAL OIL COMPANIES IN NIGER DELTA
}

\author{
Nosakhare Ikponmwosa*1, Darlington Osaremwinda Ogbeide ${ }^{2}$ \\ ${ }^{1}$ Department of Banking and Finance, Faculty of Management Sciences, University of \\ Benin, Benin City, Nigeria \\ ${ }^{2}$ Department of Business Administration, Faculty of Management Sciences, University of \\ Benin, Benin City, Nigeria \\ nosakhare.ikponmwosa@uniben.edu \\ darlington.ogbeide@uniben.edu
}

\begin{abstract}
This study examines the relationship between environmental responsibility and financial performance of international oil companies in Niger Delta region of Nigeria. In pursuance of this, a sample of twelve (12) international oil firms was used for the study. Secondary data were obtained from the audited annual financial reports of the selected companies and Federal Ministry of Environment covering the period of 2009 to 2018. The data were analyzed using descriptive statistics, correlation analysis, panel causality test and fixed effect, selected as the appropriate strategy after using the Hausman test. Based on the data analysis, the study reveals that there is a bi-directional relationship between environmental responsibility and firms' financial performance. The study further reveals that there is a positive relationship between environmental responsibility and firms' financial performance. When environmental responsibility interacts with corporate governance, the impact is found to have a significant positive relationship with firms' financial performance. The study also finds that growth opportunities and firm size are positively and significantly related to firms' financial performance. Based on the findings, the study recommends effective regulation, strong institutional mechanism and good corporate governance structures to enforce or engender environmental sustainability and compel firms to adopt the culture/strategy of sustainable finance. Such strategy will alleviate the curse of dependency and poverty that comes with the destruction of the environment and the means of sustenance of the people in oil producing communities.
\end{abstract}

Keywords: Corporate Governance, Environmental Responsibility, Environmental Sustainability, Firms' Financial Performance, International Oil Companies, Niger Delta.

JEL Classification: C23, G30, N57.

\section{Introduction}

The beneficial and adverse consequences of the activities of business on society have generated intense political, public and academic debate. At the heart of this debate is the question of how the profit (resources) of business should be appropriated and who should benefit - shareholders or stakeholders (comprising customers, suppliers, employees,

\footnotetext{
* Corresponding author: Nosakhare Ikponmwosa

Cite as:

Ikponmwosa, N., and Ogbeide, D. O., 2021. Environmental Responsibility and Firm

Financial Performance: Evidence from International Oil Companies in Niger Delta.

Oradea Journal of Business and Economics, 6(1), pp. 8-20.

http://doi.org/10.47535/1991ojbe117
} 
governments, host communities, environment and future generations). Two broad schools of thoughts have evolved over the years. First, is the philosophy that the main purpose of business is profit maximization, championed by Friedman (1970). This school argues that management of companies should focus on the Shareholders Wealth Maximization (SWM). This school is influenced by Adam Smith in the $18^{\text {th }}$ century, who argued among other things that in a free market economy, the pursuit of self-interest by individual economic agents (firms and households) invariably maximizes the welfare of society. However, we have witnessed many instances of market failures and persistent negative externalities from businesses. Examples of these include perennial oil spillage, gas flaring, and the destruction of farmland in the Niger Delta region. According to the Department of Petroleum Resources (DPR), there were over 4200 oil spill incidences in Nigeria over the last 50 years, ranging from minor spills to over half a million barrels in one single incident (Isah, 2012).

The second school of thought is Corporate Social Responsibility (CSR) which originated in the 1950s, and has been gaining ascendancy following the works of Bowen (1953), Carroll (1979), Freeman (1984) and Carroll (1999). CSR is the obligation of businesses to improve the lot of society; help solve the problem of society or at the very minimum not disrupt or destroy the community and environment in which they operate. Carroll (1999) sees CSR as the economic, ethical, legal and voluntary (philanthropic) expectations that the society places on business. Choi and Meek (2008) assert that CSR refers to accountability of a firm towards its impact on employees' welfare, the community (society) and environment. These definitions take cognizance of the Environmental, Social and Governance (ESG) dimensions of CSR. We note that Environmental Responsibility (ER) is an integral component of CSR and is the focus of this study. Olusegun (2012) defines corporate environmental responsibility as the obligation of an organization to conduct its business in such a way that environmental consequences of its activities (negative externalities) are managed with a view of neutral impact on human and biodiversity through voluntary actions and regulatory compliance. According to Aggarwal (2013:14), ER refers to "firms being accountable, by investing on sustainability of the environment and also disclosing the impacts of their activities on the environment, such as land, air, water and noise pollution." Eccles and Krzus (2010) assert that the last decades brought global concern for the long-term adverse consequences of industrial activities on the environment. The environmental impacts manifest as climate change, global warming, flooding, destruction of arable lands, and aquatic habitat among others. These stem from greenhouse gas emissions, toxic ozone - layer depleting substances, oil spills and other pollutants, including solid waste generation. Public disclosure of these information helps to portray a firm's commitment to environmental responsibility and sustainability.

\subsection{Statement of the Research Problem}

In the last decade, a number of factors have led to an increase in the interest of researchers, investors and policy makers in environmental, social and governance (ESG) dimensions of CSR. This includes the global financial crisis, climate change, and corporate scandals around the world. Whereas these challenges have constrained the ability of companies to spend on CSR, investors and companies are now increasingly aware that most pressing needs facing society requires business involvement (OECD, 2011). Taking into account the expectations of a broad range of stakeholders, especially as demonstrated during the United Nations Climate Change Conference held in Poland in December 2018 (also known as COP24), companies the world over may now be more proactive in incorporating environmental responsibilities and sustainable finance practices into their management strategy. Theoretically, this could engender financial benefits to the firms. This is because firms benefit in terms of enhanced reputation, trust, customer loyalty, access to capital, human resource management, innovation capacity and risk management (Aggarwal, 2013). 
However, in the Niger Delta region, the exploitation of oil continues to leave a tale of woe and agony on the lives and livelihood of the citizens. This is due to the destructive and devastating effects of oil exploration on the environment. For example, on December 21, 2011, Shell Nigeria announced what it describes as its worst oil spillage in a decade in the Niger Delta area. Over 40,000 barrels of crude oil spilled in one day. For over five decades, a series of similar oil spills have caused extensive damage to the ecology of the Niger Delta. Geographically, the Niger Delta is the delta of the River Niger, sitting directly on the Gulf of Guinea on the Atlantic Ocean in Nigeria. It is roughly encompassed by the South-South states in Nigeria.

The extant literature is replete with empirical evidence on the impact of oil exploration and exploitation on the environment in Nigeria (Omofonmwan and Odia, 2009; Kadafa, 2012; Uzoma and Mgbemena, 2015). However, there is paucity of empirical evidence on the relationship between environmental responsibility and the financial performance of oil companies in Nigeria. Furthermore, several studies have examined the relationship between environmental responsibility and firm financial performance over the last few decades from around the world. However, the findings provided mixed results which range from (i) positive relationship, such as Nakao et al., (2007a) in Japan, Griffin and Sun (2012) in the United State, Worea and Ngwakwe (2017) in South Africa; Elshawarby (2018) in Egypt and Etale and Otuya (2018), Sulaiman, Ahmadu, and Mijinyawa (2018), Ibrahim and Hamid (2019), and Kaoje, et al., (2020) all in Nigeria (ii) negative relationship, such as Hughes (2000); Brammer, Brooks and Pavelin (2006); Roy and Ghosh (2011) (iii) mixed relationship such as Lankoski (2000), Cormier and Magnan (2007), Orlitzky (2008) and Adewoye, Olaoye and Ogundipe (2018) (iv) no significant relationship such as Deegan (2004). Thus, in literature, the debate on the relationship between environmental responsibilities and firm financial performance remains inconclusive (Miles and Covin, 2000; Margolis and Walsh, 2003; Jo, Kim, Lee and Park, 2015). This study is therefore an attempt to contribute to the debate bordering on the relationship between environmental responsibility and firm financial performance, by focusing on International Oil Companies (IOCs) operating in Niger Delta.

Based on the foregoing, the overriding research question for the study is; what is the relationship between environmental responsibility and financial performance of international oil companies in Niger Delta? As a corollary, the study provides answer to the following specific research questions; (i) what is the direction of causation between environmental responsibility and financial performance of IOCs in Niger Delta? (ii) what is the effect of environmental responsibility on the financial performance of IOCs in Niger Delta? The motivation for this study hinges on the need to empirically provide answers to the above research questions. The choice of IOCs is due to the fact that they employ the services of reputable auditing firms which lend credence to their environmental accounting/reporting.

The rest of the study is organized as follows: section two is theoretical framework while section three describes the methodology and data employed. Section four discusses the empirical results and analysis and section five concludes the study.

\section{Theoretical Framework}

The theoretical framework is anchored on stakeholder theory, developed by Freeman (1984). Stakeholder theory emerged as an alternative to shareholder theory (Spence and Lozano, 2001). Stakeholder theory argues that businesses have accountability towards a broad range of stakeholders, apart from shareholders, which is, customers, employees, suppliers, government, community, environment, and future generations, among others. According to this view, it is not sufficient for managers to focus exclusively on the needs of shareholders, or the owners of the corporation. Stakeholder theory implies that it can be 
beneficial for the firm to engage in certain CSR activities that non-financial stakeholders perceive to be important, because, in the absence of this, these groups might withdraw their support for the firm.

Stakeholder theory was expanded by Donaldson and Preston (1995) who stressed the moral and ethical dimensions of CSR. This however, might have contributed to the introduction of ethical theory in studies of social-environmental responsibility. The theory was later expanded and is based on the idea that there is a moral imperative for managers to 'do the right thing', without regard to how such decisions affect firm financial performance. Corporate, social, and environmental responsibility helps in strengthening the relationship between firm and society in which it operates. Ignoring the stakeholder's interests may smear firm's public image, which would unfavorably affect its financial performance.

\subsection{Conceptual Model}

The conceptual model depicted in Figure 1 shows the relationship between environmental responsibility and firms' financial performance. The upper arrow depicts the direction of causation between environmental responsibility and firms' financial performance while the lower arrow and loop under shows the effect of the interaction between environmental responsibility and corporate governance on firms' financial performance. Financial performance is evaluated on the basis of two accounting variables (return on assets and return on equity). Other explanatory and control variables (firm size and firms' growth rate) are integrated in order to take into account other factors that may influence the link between the environmental responsibility and financial performance of companies. These are depicted with dotted lines.

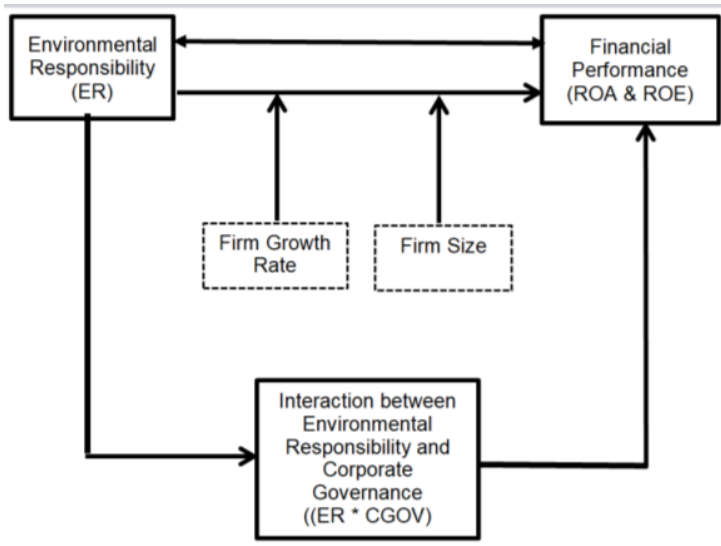

Figure 1: Conceptual Model

Source: Authors' Construction (2020).

\section{Methodology and Data}

Quantitative research method was employed for this study. The method is based on causal (ex-post facto) and longitudinal research design. Geographically, the study is confined to the Niger Delta region of Nigeria. This is where oil exploration and production takes place in Nigeria with serious consequences on the environment.

The period of the study is 2009 to 2018 . The population of the study is made up of about 131 oil companies operating in the Niger Delta. This includes IOCs, local and national oil companies, drillers and other oil services firms. In Nigeria, the permanent sovereignty and ownership over mineral resources (oil and gas) found in its geographical location are vested in the Federal Government of Nigeria, conferred under Section 44(3) of the Constitution of 
the Federal Republic of Nigeria. In terms of structure, the IOCs operate mainly under a joint venture (JV) arrangement with the Nigerian government. Under a joint venture, the Nigerian government, through the Nigerian National Petroleum Corporation (NNPC), a state-owned Federal Ministry of Petroleum Resources, acting through the Department of Petroleum of Resources, being the regulatory authority, has about 60 percent participatory interest in development and production operations of the oil fields, and therefore shares exploration, drilling and development expenditures accrued from operations. Currently, all upstream operations of major IOCs are in joint partnerships with the Nigerian government. These exploration and production companies operate predominantly in the onshore of Niger Delta in Nigeria. For the purpose of this study, however, the sample size is delimited to twelve (12) selected oil firms from among the twenty-four (24) IOCs operating in the region. The selection of the twelve (12) oil firms is based on judgmental sampling procedure. Specifically, IOCs, which employs the services of the big four auditing firms and whose data are up-to-date and readily accessible were selected. The secondary data were obtained from the audited annual financial reports of IOCs and Federal Ministry of Environment.

\subsection{Model Specification and Measurement of Variables}

In order to investigate the direction of causation between environmental responsibility and financial performance of IOCs in Niger Delta, the model developed by Granger (1969) is modified below and will be estimated:

$$
\begin{gathered}
F P M_{i t}=\beta_{0}+\sum_{k=1}^{m} \beta_{k} Y_{i t-k}+\sum_{l=1}^{n} \alpha_{j} X_{i t-j}+u_{t} \\
E R_{i t}=\gamma_{0}+\sum_{k=1}^{m} \delta_{k} X_{i t-k}+\sum_{l=1}^{n} \varphi_{j} Y_{i t-j}+\vartheta_{t}
\end{gathered}
$$

Where: $F P M_{i t}$ is Financial Performance of IOCs to be measured by firm's Return on Asset (ROA) and Return on Equity (ROE). Suffice it to say that the use of ROA and ROE are widely used accounting measures of financial performance. $E R_{i t}$ is Environmental Responsibility. Thus, two pairs of relationships are determined from the causality test. $u_{t}$ and $\vartheta_{t}=$ mutually uncorrelated error terms (i.e. zero mean white noise error terms).' $k$ ' and 'j' = the number of lags.

A growing number of studies investigate the impact of ESG dimensions of CSR on firms' financial or economic performance (Aggarwal, 2013; Ferrero-Ferrero, Fernardez-Izquierdo and Munoz-Torres, 2015). In these studies, and many others, corporate governance is seen as a stand-alone explanatory variable. However, in this study, we assume that corporate governance impact is transmitted to financial performance based on its interaction with environmental responsibility. That is, good corporate governance will enhance environmental responsibility while bad corporate governance will undermine it. Thus, the functional model below is developed for this study;

$$
F P M=f(E R * C G O V)
$$

Where CGOV is corporate governance, FPM and ER are as earlier defined. Other factors which could affect firm financial performance are added to the model as control variables. These include firms' Growth Rate (GRW) and Firm Size (FSIZE), thus equation 3 is decomposed empirically as;

$$
\begin{aligned}
& R O A_{i t}=\alpha_{0 i}+\beta_{1} E R_{i t}+\beta_{2} E R * C_{G O V_{i t}}+\beta_{3} G R W_{i t}+\beta_{4} F S I Z E_{i t}+\varepsilon_{i t} \\
& R O E_{i t}=\omega_{0 i}+\alpha_{1} E R_{i t}+\alpha_{2} E R * C G O V_{i t}+\alpha_{3} G R W_{i t}+\alpha_{4} F S I Z E_{i t}+\varepsilon_{i t}
\end{aligned}
$$


Where $\alpha$ and $\omega$ are the mean, $\beta$ and $\alpha$ are the coefficients of the explanatory variables, and $\varepsilon$ is the error term. The a priori expectations of the signs of the coefficients are given as; $\beta_{1} \& \alpha_{1}>0 ; \quad \beta_{2} \& \alpha_{2}>0 ; \quad \beta_{3} \& \alpha_{3}>0 ; \beta_{4} \& \alpha_{4}>0$. ROA is measured as the ratio of Profit after Tax (PAT) to total assets. ROE is computed as the ratio of PAT to total equity. ER was measured by IOCs commitment to environmental sustainability as evidenced by their Environmental Impact Assessment Score (EIAS). CGOV is measured by board independence (i.e. ratio of non-executive directors to executive directors), GRW is measured by growth rate of total asset and FSIZE is measured by total asset. The models are estimated using STATA econometric software, following preliminary tests, such as descriptive statistics, correlation matrix and Hausman test for fixed effect vis-à-vis random effect.

\section{Empirical Results and Analysis}

\subsection{Descriptive Statistics}

Table 1: Descriptive Statistics

\begin{tabular}{|l|c|c|c|c|c|c|c|c|}
\hline Variables & Mean & Median & Max. & Min. & $\begin{array}{l}\text { Std. } \\
\text { Dev. }\end{array}$ & $\begin{array}{l}\text { Skew } \\
\text { ness }\end{array}$ & $\begin{array}{l}\text { Kurtosi } \\
\boldsymbol{s}\end{array}$ & J-B \\
\hline$R O A$ & 25.16 & 23.05 & 78.26 & 8.28 & 6.25 & 3.25 & 12.16 & 430.20 \\
\hline$R O E$ & 27.12 & 22.25 & 85.60 & 8.40 & 7.91 & 4.80 & 25.45 & 987.24 \\
\hline$E R$ & 15.10 & 16.33 & 47.30 & 1.20 & 5.38 & 4.78 & 4.85 & 835.21 \\
\hline$E R^{\star} C G$ & 17.22 & 15.26 & 53.22 & 0.06 & 9.18 & 1.22 & 3.77 & 140.06 \\
\hline$G R W$ & 20.18 & 15.41 & 125.22 & -0.28 & 16.23 & 10.16 & 32.12 & 1875.21 \\
\hline$F S$ & 40.20 & 42.15 & 95.50 & 3.2 & 8.25 & 13.21 & 20.30 & 48.26 \\
\hline
\end{tabular}

Source: Researchers' computation using STATA (2020)

Table 1 presents the summary statistics on the two performance measures for the sampled IOCs. The descriptive statistics shows that the average return on asset for the oil firms is 25.2 which is relatively high. The median value of 23.1 percent is much less than the mean value, suggesting that the ROA values are not similar across the oil firms in the sample. This is further buttressed by the low (negative) minimum value compared to high (positive) maximum value. The standard deviation of 6.25 percent indicates high variability in the ROA values for the IOCs. The high positive skewness value further buttresses that more oil firms have ROA which are less than the observed average in the distribution. The mean value of environmental responsibility is 15.1 percent, but when interacted with corporate governance, the value becomes 17.2 percent. Apparently, the entrenchment of strong corporate governance mechanism induces a growth co-movement with the performance of IOCs. The high Kurtosis and J-B values are both evidence of an asymmetric distribution.

For the return on assets ( $R O E$ ), the mean value of 27.1 , is higher than the ROA outcome. Invariably, there appears to be wide dissimilarities among the sampled oil firms in terms of individual performance characteristics. The mean value of environmental responsibility is 15.1 percent, while that of the interaction of environmental sustainability and corporate governance is 17.2 percent. Without doubt, the presence of strong and effective corporate governance structures in IOCs will make them 'environmentally responsible'. The standard deviation value of 7.91 is also high and confirms high variability in ROE for the sampled oil firms. The descriptive statistic also revealed that all the variables used in the study are normally distributed, as observed from the Jarque-Bera (J-B) statistic. 


\subsection{Correlation Analysis}

In investigating the nature and extent of correlation among the variables, the correlation analysis is used. The result of the correlation tests is reported in table 2 below.

Table 2: Correlation Results

\begin{tabular}{|l|c|c|c|c|c|c|}
\hline Variables & $\boldsymbol{R O E}$ & $\boldsymbol{R O A}$ & $\boldsymbol{E R}$ & $\boldsymbol{E R}^{*} \mathbf{C G}$ & $\mathbf{G R W T H}$ & $\boldsymbol{F S}$ \\
\hline$R O E$ & 1 & & & & & \\
\hline$R O A$ & 0.23 & 1 & & & & \\
\hline$E R$ & 0.19 & 0.022 & 1 & & & \\
\hline$E R^{\star} C G$ & 0.03 & 0.19 & 0.02 & 1 & & \\
\hline$G R W$ & 0.35 & 0.43 & 0.28 & 0.21 & 1 & \\
\hline$F S$ & 0.41 & -0.39 & 0.16 & 0.19 & 0.25 & 1 \\
\hline
\end{tabular}

Source: Researchers' computation using STATA (2020)

In the correlation matrix, a positive relationship is observed between ROE and each of the other variables. In the same vein, ROA has positive relationship with the variables except for firm size. This implies that there is a co-movement between environmental sustainability and the performance of IOCs. The correlation between the independent variables show that environmental sustainability is positively correlated with the interactive of corporate governance and environmental investment; an implication that both variables reinforce each other. In the same vein, firm size is positively correlated with growth size. Invariably, higher firm size implies better growth opportunities, vice versa,

\subsection{Panel Causality Test}

In order to determine the direction of causation between environmental responsibility and financial performance of IOCs in the Niger Delta, the panel causality test is conducted. The results are reported in Table 3.

Table 3: Panel Causality Test

\begin{tabular}{|c|c|c|}
\hline Null Hypothesis & \multicolumn{2}{|c|}{ Causality Tests } \\
\hline ROA does not Granger cause ER & $\begin{array}{l}\text { W-bar } \\
\text { Z-bar } \\
\text { Z-bar tilde }\end{array}$ & $\begin{array}{l}7.22^{\star \star *}(0.000) \\
6.02^{\star \star *}(0.000) \\
5.95^{\star *}(0.000)\end{array}$ \\
\hline ER does not Granger cause ROA & $\begin{array}{l}\text { W-bar } \\
\text { Z-bar } \\
\text { Z-bar tilde }\end{array}$ & $\begin{array}{l}4.10^{\star \star \star} \\
8.32^{\star * \star}(0.000) \\
7.344^{\star * *}(0.00)\end{array}$ \\
\hline ROE does not Grange cause ER & $\begin{array}{l}\text { W-bar } \\
\text { Z-bar } \\
\text { Z-bar tilde }\end{array}$ & $\begin{array}{l}2.98^{\star \star *} \\
3.45^{\star \star *}(0.0006) \\
2.78^{\star \star \star}(0.0058)\end{array}$ \\
\hline ER does not Granger cause ROE & $\begin{array}{l}\text { W-bar } \\
\text { Z-bar } \\
\text { Z-bar tilde }\end{array}$ & $\begin{array}{l}2.32^{* \star} \\
2.45^{\star * *}(0.007) \\
2.802^{\star \star \star}(0.0058)\end{array}$ \\
\hline
\end{tabular}

Source: Researchers' computation using STATA (2020)

The results indicate that in all the cases, we reject the null hypotheses. This implies the existence of feedback or bidirectional causation between environmental responsibility and financial performance of IOCs. Invariably, environmental responsibility tends to enhance financial performance, and in the same vein, financial performance tends to induce greater level of environmental responsibility on the part of international oil firms. 


\subsection{Panel Multivariate Analysis}

In this section, an attempt is made to empirically examine the effect of environmental responsibility and other explanatory variables on the performance of international oil companies. The analysis is based on the panel data approach. We specifically analyzed our performance measures with the pooled OLS and the fixed effect approaches. A choice is made between these two approaches using the standard F-statistics. We also estimated the model with the random effect approach, however, using the Hausman test, the fixed effect is chosen as the best model. The result is presented in table 4.

Table 4: Panel Regression Results: Dependent Variable: ROA \& ROE

\begin{tabular}{|c|c|c|c|c|}
\hline \multirow[t]{2}{*}{ Variables } & \multicolumn{2}{|c|}{ Pooled OLS } & \multicolumn{2}{|c|}{ Fixed Effect } \\
\hline & $(1)$ & $(2)$ & (3) & (4) \\
\hline Constant & $\begin{array}{l}0.013 \\
(0.75)\end{array}$ & $\begin{array}{l}0.081^{*} \\
(1.73)\end{array}$ & $\begin{array}{c}1.178^{*} \\
(0.964)\end{array}$ & $\begin{array}{l}1.021^{*} \\
(1.70)\end{array}$ \\
\hline ER & $\begin{array}{l}0.129^{\star} \\
(1.86)\end{array}$ & $\begin{array}{l}0.114 \\
(0.68) \\
\end{array}$ & $\begin{array}{l}0.152^{*} \\
(1.63)\end{array}$ & $\begin{array}{l}0.294 \\
(1.16) \\
\end{array}$ \\
\hline $\mathrm{ER} \times \mathrm{CG}$ & $\begin{array}{l}0.263^{*} \\
(1.13)\end{array}$ & $\begin{array}{c}0.133^{*} \\
(1.764)\end{array}$ & $\begin{array}{l}0.062^{\star *} \\
(2.426)\end{array}$ & $\begin{array}{l}0.185^{\star *} \\
(2.250)\end{array}$ \\
\hline GRW & $\begin{array}{l}0.052^{*} \\
(1.74)\end{array}$ & $\begin{array}{l}0.205^{*} \\
(2.14)\end{array}$ & $\begin{array}{c}0.244 \\
(1.952)\end{array}$ & $\begin{array}{c}0.335^{\star \star *} \\
(2.71)\end{array}$ \\
\hline FS & $\begin{array}{l}-0.06^{*} \\
(-2.18)\end{array}$ & $\begin{array}{c}-0.320^{*} \\
(-1.41)\end{array}$ & $\begin{array}{l}0.411^{\star *} \\
(2.140)\end{array}$ & $\begin{array}{c}0.262^{*} \\
(1.980)\end{array}$ \\
\hline Adjusted $\mathrm{R}^{2}$ & 0.14 & 0.17 & 0.62 & 0.60 \\
\hline Durbin-Watson & 0.92 & 1.16 & 1.66 & 1.78 \\
\hline F-statistics & $15.20^{* * *}$ & $17.25^{\star \star \star}$ & $32.96^{\star * *}$ & $41.27^{\star \star \star}$ \\
\hline
\end{tabular}

Note: ${ }^{* * *},{ }^{* *} \&{ }^{*}$ indicate $1 \%, 5 \% \& 10 \%$ level of significance; Standard F-test to choose between Pooled OLS \& Fixed Effect Models; T-ratios are in parenthesis; Pooled OLS (Model 1 \& 2); Fixed Effect (Model 3 \& 4).

Source: Researchers' computation using STATA (2020)

Using the standard F-statistics test approach to chosen between the Pooled OLS and the Fixed Effect models, table 4 reveals that the fixed effect is the best estimation technique. Our analysis and policy perspective are therefore based on the fixed effect.

The adjusted $R^{2}$ both performance measures (ROA \& ROE) for the sampled international oil firms based on the fixed effect show that over 62 percent and 60 percent of the net systematic variations in ROA and ROE are explained by the exogenous variables. The F-value for ROA is 32.96 and 41.27 for ROE are both significant at the 1 percent level respectively. Invariably, there is clear evidence of a significant linear relationship between the respective performance measures and the explanatory variables combine. The Durbin-Watson statistic for both performance measures of 1.66 and 1.78 show the absence of autocorrelation in the results, making the estimated models fit for structural and policy perspectives.

In terms of the coefficients of the explanatory variables, environmental responsibility variable for both performance measures are positively signed in line with economic expectation, but are not significant at the 5 percent level. Thus, IOCs have been involved in environmentally sustainable policies, particularly in terms of investment and environmental impact assessment score, which shows the extent of environmental involvement, engagement and responsibility of such companies, given the detrimental effect of 
environmental degradation. The impact is however weak, given insignificance of the respective t-ratios. Since the t-value is greater than unity, we may infer that environmental sustainability has had some impact on the Niger-Delta region, particularly the host communities and environment, where large scale destruction of the biosphere has been evident, but the impact is weak. The finding supports the results of Nakao et al. (2007a), Griffin and Sun (2012), Worea and Ngwakwe (2017), Etale and Otuya (2018), Sulaiman, Ahmadu and Mijinwa (2018), Ibrahim and Hamid (2019), and Kaoje et al. (2020).

The coefficient of the interaction of environmental responsibility with corporate governance (measured by board independence) is positive and significant at the 5 percent level. Invariably, good corporate governance strengthens environmental responsibility. The finding is in line with the studies of Rao, Tilt and Lester (2012), and Elshawarby (2018).

The coefficient of growth opportunity for both performance measures (ROA \& ROE) is appropriately positive in line with apriori expectation and is significant at 1 percent level. This implies that better growth opportunities tend to enhance the performance of international oil firms to disclose environmental issues. This finding corroborates the findings of Nakao et al. (2007a) and is at variance with the findings of Roy and Ghosh (2011). The coefficient of firm size is positive and passes the significance test at both the 5 percent and 10 percent level for ROA and ROE, respectively. Thus, large firm size tends to enhance performance in IOCs, especially, as it allows better economies of scale and efficiency in the use of resources. The finding supports the findings of Setyorini and Ishak (2012), and Sulaiman, Ahmadu and Mijinwa (2018).

\subsection{Policy Implications of Findings}

A number of important policy implications emanates from this study as follows:

(i) Environmental responsibility has a positive effect on firm financial performance in Nigeria. Thus, as international oil companies (IOCs) engage more in environmental responsibility activities, their acceptance and patronage are encouraged for greater financial performance.

(ii) Interaction of environmental responsibility with corporate governance produces more significant effect on the financial performance of international oil firms in Nigeria. Thus, without strong corporate governance structures on the activities of international oil firms, the extent of their environmental responsibility and corporate social responsibility may be diminished. By implication, strong and effective corporate governance structures are needed to make international oil companies (IOCs) environmentally responsible in Nigeria.

(iii) Improved growth opportunities have the capacity to steer the performance of IOCs in Nigeria, as it presents them with robust performance prospect, and in turn, enable them become more socially and environmentally responsible. Therefore, policies to encourage the growth opportunity of oil firms should be encouraged.

(iv) The larger the size of IOCs, the better and more improved financial performance they are likely to have. Invariably, firms with larger size tend to enjoy greater economies of scale that enable them realize better financial performance, and in turn, become more environmentally responsible.

\section{Conclusion and Recommendations}

The environmental destruction in oil producing communities in the Niger Delta region is enormous. In this respect, the continued underdevelopment of the region in the midst of the vast oil resources is a paradox. This study has examined the impact of environmental responsibility on the financial performance of oil firms in the region by employing panel causality and multivariate panel data approach. In terms of the causality results, environmental responsibility is found to have a bi-directional relationship with ROA and ROE, implying a mutually reinforcing effect between them. Nevertheless, there is a positive 
relationship between environmental responsibility and firm's financial performance of IOCs. The interaction of strong and effective corporate governance mechanism is found to be significant. Other variables found to be significant to financial performance of oil companies are growth opportunities and firm size.

The clear import of these findings is that corporate governance mechanism needs to be strongly instituted in order to strengthen environmental sustainability and other corporate social responsibility of these international oil companies to their host communities and the environment. In other words, as part of their strategic planning and implementation, management of IOCs should consider investments in the environment in which they operate. Also, effective regulation, strong institutional mechanism and good corporate governance structures are required to enforce environmental sustainability and compel firms to adopt the culture/strategy of sustainable finance. Such strategy will alleviate the curse of dependency and poverty that comes with the destruction of the environment and the means of sustenance of the people in oil producing communities. In this regard, sustainability investment, transparency, accountability, youth-literacy, community participation, engagement and other forms of host communities' involvement are required on the part of IOCs. We believe that ultimately, environmental responsibility and sustainability strategies will engender ample financial benefits to shareholders and other stakeholders.

\subsection{Limitation(s) of the Study and Future Research}

The limitation of this study is its focus on international oil companies (IOCs), to the neglect of firms in the mining, quarrying and manufacturing sectors. The activities of firms in those sectors might also have significant environmental consequences. Future line of research should therefore include the activities of these sectors. Also, future research should explore the use of survey to gauge the perception of stakeholders on the level of environmental responsibility exhibited by oil firms.

\section{Acknowledgements}

We acknowledged the support of different authors in the areas of corporate social responsibility and environmental responsibility whose literature were reviewed in this study. We also appreciate the international oil companies operating in the Niger Delta Region of Nigeria and Federal Ministry of Environment for the various academic resources used for this study.

\section{References}

Adewoye, J.O., Olaoye, C.O. and Ogundipe, A.A. 2018. Corporate social responsibility and performance of oil and gas industry in Nigeria. EKSU Journal of the Management Scientists, 2 (1), pp.97-106.

Aggarwal, P., 2013. Relationship between environmental responsibility and financial performance of firm: A literature review. Journal of Business and Management, 13 (1), pp.13-22. https://doi.org/10.9790/487X-1311322.

Bowen, H. 1953. Social responsibility of the businessman. New York: Harper \& Row.

Brammer, S., Brooks, C. and Pavelin, S. 2008. Corporate social performance and stock returns: UK evidence from disaggregate measures. Financial Management, 35 (3), pp.97 116. https://doi.org/10.1111/i.1755-053X.2006.tb00149.x.

Carroll, A. 1979. A three-dimensional conceptual model of corporate performance. The Academy of Management Review, 4 (4), pp. 497 - 505. https://doi.org/10.5465/amr.1979.4498296. 
Carroll, A. 1999. Corporate social responsibility: Evolution of a definitional construct. Business \& Society, 38(3), pp.268 - 295. https://doi.org/10.1177/000765039903800303.

Choi, F.O. and Meek, G. 2008. International accounting, $6^{\text {th }}$ Ed., New Jersey: Pearson Prentice Hall.

Cormier, D. and Magnan, M. 2007. The revisited contribution of environmental reporting to investors' valuation of a firm's earnings: An international perspective. Ecological economics, 62(3), pp.613-626. https://doi.org/10.1016/j.ecolecon.2006.07.030.

Deegan, C. 2004. Environmental disclosures and share prices: A discussion about efforts to study this relationship. Accounting Forum, 28 (1), pp.87-97. https://doi.org/10.1016/i.accfor.2004.04.007.

Donaldson, T. and Preston, L. E. 1995. The stakeholder theory of the corporation: Concepts, evidence, and implications. Academy of Management Review, 20 (1), pp.65-91. https://doi.org/10.5465/amr.1995.9503271992.

Eccles, R.G. and Krzus, M. 2010. One report: Integrated reporting for a sustainable strategy, New Jersey: John Wiley \& Sons, Inc., Hoboken.

Elshawarby, M. 2018. The effect of environmental and social corporate governance on the financial performance with special on the Egyptian private sector companies within Egx30. Journal of Accounting and Marketing, $7 \quad$ (2), pp. 269-290. https://doi.org/10.4172/2168-9601.1000269.

Ferrero-Ferrero, I., Fernardez-Izquierdo, M. and Munoz-Torres, M.J. 2015. Integrating sustainability into corporate governance. An empirical study on board diversity. Corporate Social Responsibility and Environmental Management, 22 (4), pp.19 - 32. https://doi.org/10.1002/csr.1333.

Etale, L.M. and Otuya, S. 2018. Environmental responsibility reporting and financial performance of quoted oil and gas companies in Nigeria. European Journal of Business and Innovative Research, 6 (6), pp.23-34. https://doi.org/10.37745/ejbir.2013 or https://www.eajournals.org/journals/european-journal-of-business-and-innovation-research -ejbir/vol-6-issue-6-december-2018/.

Freeman, R.A. 1984. Strategic management: A stakeholder approach. Boston: Pitman Publishing Inc., USA.

Friedman, M. 1970. A Friedman doctrine. The social responsibility of business is to increase profit. New York Time Magazine, September 13, 126.

Granger, C.W.J. 1969. Investigating causal relationships by economic models and cross-spectral methods. Econometrica, 37(3), pp.424 - 438. https://doi.org/10.2307/1912791.

Griffin, P. A. and Sun, E.Y. 2012. Going Green: Market reaction to CSR Newswire Releases (January 29, 2012). Journal of Accounting and Public Policy, 32 (2), Available at SSRN: https://ssrn.com/abstract=1995132 or http://doi.org/10.2139/ssrn.1995132.

Hughes, K. 2000. The value relevance of non-financial measures of air pollution in electric utility industry. The Accounting Review, 75 (2), pp.209 - 228. https://doi.org/10.2308/accr.2000.75.2.209.

Ibrahim, M. and Hamid, K.T., 2019. Corporate social responsibility and financial performance of listed non-financial services companies in Nigeria. American Journal of Business and Society, 4 (2), pp.56-71. Available at http://www.aiscience.org/journal/ajbs. Isah, M.N. 2012. The role of environmental impact assessment in Nigeria's oil and gas industry. PhD Thesis, Cardiff University, United Kingdom.

Jo, H., Kim, H. and Park, K. 2015. Corporate environmental responsibility and firm performance in the financial service sector. Journal of Business Ethics, 131, pp.1-65. https://doi.org/10.1007/s10551-014-2276-7.

Kadafa, A. 2012. Environmental impact of oil exploration and exploitation in the Niger Delta of Nigeria. Environment Global Journal of Science Frontier Research, 12 (3), pp.19-28. 
Available

https://globaljournals.org/GJSFR Volume12/2-Environmental-Impacts-of-Oil-Exploration.p df.

Kaoje, A.N., Sani, A.B., Tanko, G.I., Babangida, M.A., and Yabo, A.S. 2020. The implication of corporate social cost on the profitability of oil marketing companies in Nigeria. IOSR Journal of Business and Management (IOSR-JBM), 22 (1), pp.51-56. https://doi.org/10.9790/487X-2201025156.

Lankoski, L. 2000. Determinants of environmental profit: An analysis of firm level relationship between environmental performance and economic performance. Doctoral Dissertation, Helsinki University of Technology.

Margolis, J. D. and Walsh, J. P. 2003. Misery loves companies: Rethinking social initiatives by business. Administrative science quarterly, 48 (2), pp.268-305. https://doi.org/10.2307/3556659.

Kathy Rao, K., Tilt, C, and Lester, L. 2012. Corporate governance and environmental reporting: An Australian study. Corporate Governance, 12 (2), pp. 143-163. https://doi.org/10.1108/14720701211214052.

Miles, M. P. and Covin, J. 2000. Environmental marketing: A source of reputational, competitive, and financial advantage. Journal of Business Ethics, 23 (3), pp.299-311. https://doi.org/10.1023/A:1006214509281.

Nakao, Y., Nakano, M., Amano, A., Kokubu, K., Matsumura, K. and Gemba, K., 2007a. Corporate environmental and financial performances and the effects of information-based instruments of environmental policy in Japan. International Journal of Environmental and Sustainable Development, 6 (1), pp.95 - 112. https://doi.org/10.1504/IJESD.2007.012739. OECD (2011). Towards green growth, Paris: OECD Publishing, France.

Omofonmwan, S. and Odia, O., 2009. Oil exploitation and conflict in the Niger-Delta region of Nigeria. Journal of Humanity Ecology, 26 (1), pp.25-30. https://doi.org/10.1080/09709274.2009.11906161

Orlitzky, M. 2008. Social-environmental responsibility and financial performance: A research synthesis, in: A. Crane, A. McWilliams, D. Matten, J. Moon and D. S. Siegel (ed.), The Oxford Handbook of Corporate Social Responsibility, Oxford: Oxford University Press.

Olusegun, M.V. 2012. The impact of corporate environmental responsibility on financial performance: Perspective from multinational extractive sector. Doctoral Dissertation, Brunel University, West London.

Roy, A. and Ghosh, S.K., 2011. The bilateral association between discretionary environmental disclosure quality and economic performance. An Asian perspective. The IUP Journal of Accounting Research and Audit Practices, 10 (2), pp.7-27. Available at https://EconPapers.repec.org/RePEc:icf:icfjar:v:10:y:2011:i:2:p:7-27

Setyorini, C.T. and Ishak, Z. 2012. Corporate social and environmental disclosure: A positive accounting theory viewpoint. International Journal of Business and Social Science, 3 (9), pp.152-163. Available at https://ijbssnet.com/journals/Vol 3 No 9 May 2012/17.pdf Spence, L. and Lozano, J. 2000. Communicating about ethics with small firms: Experiences from the United Kingdom and Spain. Journal of Business Ethics, 27 (1/2), pp.43-53. https://doi.org/10.1023/A:1006417425446

Sulaiman, A. S., Ahmadu, A. and Mijinyawa, U. M. 2018. Effect of corporate social responsibility expenditure on the profitability of listed oil and gas firms in Nigeria. Journal of Accounting and Management, 1 (2), pp.148-154. Available at https://www.researchgate.net/publication/333566299.

Uzoma, A.C. and Mgbemena, O.O. 2015. Evaluation of some oil companies in the Niger Delta region of Nigeria: An environmental impact approach. International Journal of Environmental and Pollution Research (IJEPR), 3 (3), pp.13-31. Available at 
https://www.eajournals.org/journals/international-journal-of-environment-and-pollution-rese arch-ijepr/vol-3issue3-august-2015/

Worae, T.A. and Ngwakwe, C.C. 2017. Environmental responsibility and financial performance nexus in South Africa: Panel Granger Causality Analysis. Environmental Economics, 8 (3), pp.29-34. http://dx.doi.org/10.21511/ee.08(3).2017.03

\section{Bio-Note}

Nosakhare Ikponmwosa (Ph.D.) is a lecturer in the department of Banking and Finance, Faculty of Management Sciences, University of Benin, Benin city, Nigeria. Dr. Ikponmwosa's research interest includes corporate finance and asset pricing. He has publications in local, national and international journals.

Darlington Osaremwinda Ogbeide (Ph.D.) is a lecturer in the department of Business Administration, Faculty of Management Sciences, University of Benin, Benin city, Nigeria. Dr Ogbeide's research interest is in the area of international business, marketing, operations management and supply chain management. $\mathrm{He}$ is a member of the Academy of Management Nigeria. He has publications in local, national and international journals. 